\section{AKTIVITAS ENZIM LIPASE ALKALI DARI BAKTERI DALAM SURFAKTAN}

\section{Oleh : V. Sri Pertiwi Rumiyati' dan Retno Indrati}

\section{ABSTRACT}

Activity and stability of alkaline lipase from bacteria (strain AS, KB and SP) were studied in Activity and stability of alkaline lipase $0,10 \%$. The surfactanswere used in research, these containing of surfactants at $0,05 \%$ and $0,10 \%$, niaproof $n$ - lauroyl sarcosine, dehydrocholic were consisted of four anionic surfactants (SDS, niaproof, n-lauroyl sarcosine, dehydium chlo acid), three cationic surfactants (cetyl trimethyl ammonium bromide, cetyl pyridium chloride cetyl dimethyl ammonium bromide) and three nonionic surfactants (Triton $X-100$ ride, cetyl dimethyl ammonim tergitol, and nonidet $P$-40.). Production of enzyme was produced in initial medilitine lipase from incubation at $37^{\circ} \mathrm{C}$ for $48 \mathrm{~h}$. These researsch showed that activity of alkaline lipase from strain $A S-1 ; A S-2 ; K B-4 ; S P-2$ and $S P-13$ was stable in containing of anionic starfac tants 8 and $S P$ - 1 were showed decrease of activity (relanif activity < 80 ). Strain KB - 4 in prodused alkaline lipase which stable in containing of anionic surfactants, cationic surfactants and nonionic surfactants at $0,05 \%$ \& $0,10 \%$. It was had high activity (activity relatif $90-125 \%)$.

\section{INTISARI}

Antabilitas entim lipase alkali dari bakteri yang berasal dari isolat $A S, K B$ dan

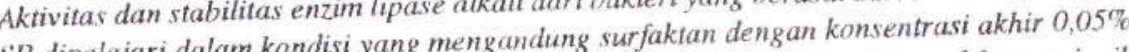
$S P$ dipelajari dalam kondisi yang mengandung surfaktan dengan konsentras aktan anionik dan $0,10 \%$ Surfaktan yang digunakan dalam penelitian adalah empat jenis surfakim arik SDS, niuproof, n-laumyl sarcosine, dehydrocholic acid), tig a jenis surfaktan kationik (cetyl (SDS, niaproof, n-lauroyl sar sosine, dehydium chloride, cetyl dime thyl ammonium bromida) dan tiga jenis surfaktat nonionik (triton $X-100$, lergitol, dan monidel $P$ - 40 ). Produksi enzim lipase dilaksanakan pada media dengan $\mathrm{pH}$ awal 7,5, suhu inkubasi $37 \mathrm{C}$ selama 48 jan. Hasil penelitian memunjukkan bahwa aktivitas enzim lipase alkali yang berasal dari jon 列 surjaktan anionik, Kationik dan non iatif $<80 \%$ ). Isolat $K B-4$ memproduksi enzim lipase aktivitasnya menurun (aktivitus relatif < so\%). Kolai KB alkali stabil pada kondisi yang mengandung surfaktan anюnik, kationik dan nos

dan $0,10 \%$. Enzim tersebut mempunyai aktivitas relatif tinggi $(90-125 \%)$.

\section{PENDAHULUAN}

Finzime lipase (EC 3.1.1.3) adalah eazim yang menghidrolisis ester pada bidang antara minyak-air dalam substrat yang tidak larut air atau sistem yang heterogen (Shanani, 1975 dalam Reed, 1984). Substrat bagi eazim lipase adalah

1. Balai Besar litbang Kulit, Kareı dan Plastik (BBKKP), Yogyakarta.

1. Balai Besar Litbang Keknologi Pertanian Universitas Gadjah Mada, Yogyakaria. digliserida, monogliserida, asam lemak bebas dan gliserol. Sumber enzim lipase dapat diperoleh dari jamur (Brockerhoff dan Jensen, 1974; Ohnishi dkk., 1994; Xia dkk., 1996) serta dari bakteri seperti Pseudomonas, Achromobacter. Staphyloccoccus dan lain-lain (Crueger dan Crueger, 1989; Lin dkk., 1996). Lipase alkali adalah enzim lipase yang aktif dalam kondisi alkali, enzim tersebut telah dapat diekstrak dari jenis bakteri seperti Pseudomonas sp., Bacillus sp., Alcaligenes spp, dan lain-lain (lin dkk., 1996; Kojima dkk., 1994; Lesuisse dkk. 1993; Kokusho dkk., 1982). Enzimtersebut dapat diaplikasikan dalam berbagai industri seperti industri penyamakan kulit untuk penghilangan minyak/lemak alami kulit, industri minyak dan industri deterjen untuk meningkatkan daya pencucian. Aktivitas enzim lipase dipengaruhi oleh beberapa faktor antara lain konsentrasi enzim, pH, suhu, adanya ion dan surfaktan (Linfield dkk., 1984; Khor dkk., 1986; Hammond dan Glantz, 1988). Pengaruh surfaktan terhadap enzim li pase dipelajari oleh Xia dkk (1996) dan Lin dkk (1996) pada mikroba yang berbeda yaitu Penicillium cyclopium dan Neurospora TT - 241. Adanya surfaktan dalam enzim lipase akan berpengaruh terhadap aktivitas enzimnya. Faktor-faktor yang mempengaruhi aktivitas enzim lipase dengan adanya surfaktan adalah jenis surfaktan, konsentrasi surfaktan yang ditambahkan serta jenis enzim yang digunakar (Xia dkk., 1996; Lin dkk., 1996). Metoda kuantitatif aktivitas enzim lipase dapa dibedakan menjadi tiga kelompok yaitu mengukur perubahan fisik dalam sistem reaksi, menguji alkohol yang dibebaskan dan menguji asam lemak yang dibebaska (Brockerhoff dkk, 1974). Dari ketiga metode tersebut yang paling umum digunakat adalah metoda yang ketiga yaitu menguji asam lemak yang dibebaskan. Beberap: metoda analitik yang dapat digunakan untuk menghitung aktivitas lipase antar: lain dengan metoda Stat-Potentiometric, metoda gel silica dan metoda Manometri Warburg (Budiatman dkk, 1993). Ketiga metode tersebut prinsip dasarny: menghitung jumlah asam lemak bebas yang dibebaskan.

Bakteri yang digunakan untuk penelitian diisolasi dari kulit hewan, penelitia isolasi bakteri penghasil enzim lipase dari kulit telah dilaporkan dalam pape sebelumnya. Dalam paper ini akan dikaji tentang aktivitas enzim lipase alkali dar bakteri dengan adanya berbagai jenis surfaktan pada konsentrasi yang berbeda.

\section{MATERI DAN METODA}

\section{Materi Penelitian}

1. Mikroorganisme

Isolat yang digunakan untuk penelitian adalah isolat AS - $1 \mathrm{AS}-3, \mathrm{~KB}-4 \mathrm{~KB}-8$ SP - 1, SP - 2 dan SP - 13 diisolasi dari kulit ayam, kambing dan sapi (Rumi ya dan Indrati, 1998)

2. Surfaktan

Surlaktan yang digunakan terdiri atas tiga jenis yaitu anionik, kationik dan no 
ionik. Jenis anionik yaitu SDS, niaproof, $\mathrm{n}$-lauroyl sarcosine, dehydrocholic acid; jenis surfaktan kationik yaitu cetyl trimethyl ammonium bromide, cetyl pyridium chloride cetyl dimethyl ammonium bromide; dan surfaklan non ionik yaitu Triton X - 100, tergitol, dan nonidet $P$ - 40 .

3 Media untuk analisa terdiri atas larutan buffer Tris- II I $\mathrm{PlI}$ 8.0, minyak olive, polivynyl alkohol, $\mathrm{CaCl}_{2}, \mathrm{C}_{2} \mathrm{H}_{5} \mathrm{OH}$, larutan $\mathrm{NaOh} 0.01 \mathrm{~N}, \mathrm{NaOH} 0.8 \mathrm{~N}$, asam oksalat, indikator phenolphtalein.

4. Media untuk produksi enzim

Setiap liter media mengandung $0,50 \%$ pepton, $0,05 \% \mathrm{MgSO}_{4}, 0,10 \% \mathrm{KH}_{2} \mathrm{PO}_{4}$, $0,10 \% \mathrm{NaNO} 3,0,50 \%$ sorbitol dan $1,00 \%$ v/v minyak sawit (Indarti dan Rumiyati, 1998).

Alat Penelitian

Alat penelitian meliputi inkubator (Fisher Scientific), inkubator bergoyang, ultrasentrifuge (combi), $\mathrm{pH}$-meter (Jenway), timbangan analitik, vortex, penangas air, pipetman Gilson, thermometer, stop watch, serta peralatan gelas

Metoda Penelitian

Penelitian dilakukan dalam tiga tahap yaitu :

1. Produksi enzim

Sel dari setiap isolat ditumbuhkan pada media produksi (pH 7.5) dalam inkuba tor bergoyang, selama $48 \mathrm{jam}$, suhu $37^{\circ} \mathrm{C}$. Kullur media yang diperoleh disentr fuse pada $2000 \mathrm{~g}$, suhu $4^{\circ} \mathrm{C}$ selama 20 menit. Supernatan yang herisi en $i m$ eks traseluler menupakan enzim kasar, kemudian diuji aktivitas enzim lipasenya pada kondisi yang mengandung surfaktan

2. Uii aktivitas enzim lipase pada kondisi yang mengandung surf:tktan Setiap enzim kasar hasil ekstraksi dari setiap isolat yang digunakan, liuj aktiv las enzimnya pada kondisi yang mengandung surfaktan dengan variabel jenis surfaktan dan kensentrasi akhir surfaktan dalam cmulsi minyak yaitu $0,05 \%$ dan $0,10 \%$.

3. Pengujian enzim

(10)5) dan Koh no dkk (1994) dengan sedikit modifikasi. (ampuran antara $4 \mathrm{ml}$ emulsi minyak dive 40 ul ( $12.2112020 \mathrm{mM}$; diinkuhasikan pada suhu $37^{\circ} \mathrm{C}$ selama 5 me nit, dalam penangas air bergoyang, $2 \mathrm{ml}$ larutan enzim yang telah mengandung

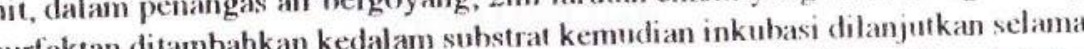
30 menit. Untuk menghentikan reaksi diambil $6 m 1$ etanol dimasukkan dalam campuran tersebut, kemudian dititrasi dengan $\mathrm{NaOH} 0.01 \mathrm{~N}$, menggunakan indi kator PP sampai pH 9.0. Untuk perlakuan blanko, enzim yang ditambahkan ke dalam substrat dihentikan terlebih dahulu aktivilas enzimnya, dengan menambal etanol. Emulsi minyak olive disiapkan dengan mancampur polyvinyl alcohol $2 \%$ dalam buffer Tris- HCl pH 8,0 dengan perbandingan minyak olive : PVA 1:2 $\mathrm{v} / \mathrm{v}$.

Vol XIVNo 26 Th $1998 / 1999$
Satu unit aktivitas enzim lipase didefinisikan sebagai sejumlah enzim yang mem bebaskan 1 umol equivalent asam lemak bebas dari minyak olive dalam satu me nit pada kondisi analisa (Xia dkk, 1996). Aktivitas enzim lipase dapat dihitung dengan rumus

$$
10 \times(\mathrm{S}-\mathrm{B}) \times f
$$

$\mathrm{U} / \mathrm{ml}=$

$$
\text { VT }
$$

Keterangan :

$\mathrm{S}=$ volume $\mathrm{NaoH}$ yang digunakan untuk titrasi sampel

$\mathrm{B}=$ volume $\mathrm{NaOH}$ yang digunakan untuk tritasi blanko

$\mathrm{f}=$ faktor pengenceran enzim lipase

$\mathrm{V}=$ volume enzim lipase yang diuji $(\mathrm{ml})$

$\mathrm{T}=$ waktu reaksi

$10=$ umol $\mathrm{NaoH}$ yang terdapat dalam $1 \mathrm{ml} 0.01 \mathrm{~N} \mathrm{NaON}$

\section{HASIL DAN PEMBAHASAN}

Hasil penelitian aktivitas enzim lipase pada kondisi yang mengandung surfaktan dianalisa berdasarkan aktivitas relatif yaitu perbandingan antara aktivitas enzim lipase yang diuji pada kondisi yang mengandung surfaktan dengan aktivitas enzim lipase yang diuji pada kondisi tanpa mengandung surfaktan, dan dinyatakan sebagai persen. Aktivitas relatif $100 \%$ adalah aktivitas enzimlipase yang diuji tanpa perlakuan dengan surfaktan (kontrol).

Pengaruh surfaktan terhadap aktivitas relatif enzim lipase disajikan pada ganbar 1. sampai 3. Dari hasil penelitian menunjukkan bahwa pemakaian SDS $0,05 \%$ dan $0,10 \%$ relatif stabil, tidak mempengaruhi aktivitas enzim lipase yang berasal dari isolat AS (Gambar 1.)' Isolat KB (Gambar 2.), Isolat SP-1 dan SP-13 (Gambar 3a.dan 3c.). Hal tersebut ditunjukkan dengan aktivitas relatif $>80 \%$, sedang terhadap aktivitas enzim lipase yang berasal dari isolat SP-2 (Gambar 3b.) menurunkan aktivitas (aktivitas relatif $<80 \%$ ). Hasil tersebut berbeda dengan penelitian yang dilakukan oleh Lin dkk (1996) yang melaporkan bahwa pemakaian SDS dengan kosentrasi $0.1 \%(\mathrm{~b} / \mathrm{v})$ menghambat aktivitas enzim lipase yang berasal dari Neurospora sp TT -241 , sedang peneliti yang lain melaporkan bahwa penggunaan surfaktan anionik (SDS) pada konsentrasi yang rendah $(3.2-40 \mathrm{uM})$ meningkatkan aktivitas enzim dari Penicillium cyclopium, sedang pada konsentrasi 
lebih besar 5.6 uM SDS menurunkan aktivitas enzim sacara linier (Xia dan Nnanna, 1996)
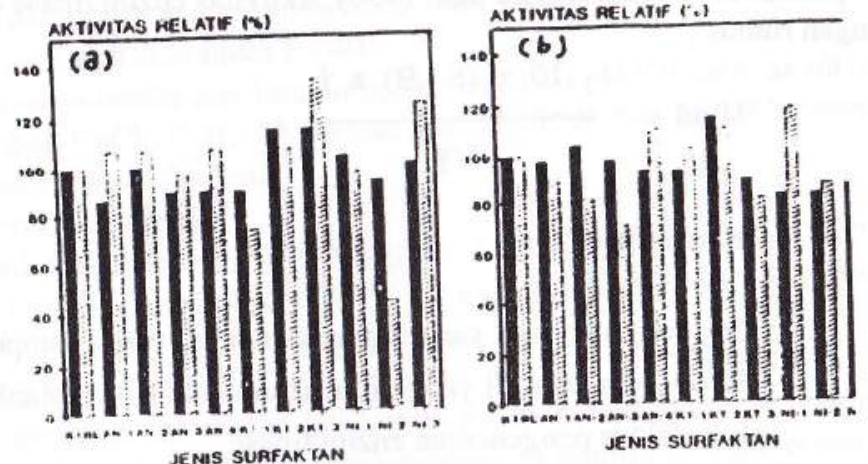

jambar 1. Pengaruh surfaktan terhadap aktivitas enzim lipase daı AS - 1 (a) dan AS - 3 (b)

AN 1, SDS: AN - 2, Niaproof; AN - 3, N-lauroly sarcosi ne $\mathrm{AN}-4$, Dehydrocho-lic acid; K1-1, Cetyl trimetyl an bromide; KT-2, Cetyl pyridium chloride; KT 3 , Cetyl dimetyl amonium bromide; NI-1, Triton X 100; Ni-2 Tergitol dan NI-3, Nonidet P-40.

Pemakaian n-lauroyl sarcosine $0.10 \%$ berpengaruh terhadap aktivitas enzim lipase dari AS-3, SP-1 dan SP-13, sedang dehydrocholic acid berpengaruh terhadap aktivitas enzim lipase dari SP-13 yaitu menurunkan aktivitas relatifnya. Pada fonik pada konsentrasi rendah berinteraksi dengan protein momplek yang menjadi lebih aktif dibanding lipase, sehingga akan memecah substrat dan meningkatkan aktivitas lipolisis, namun pada konsentrasi yang tingi akan memacu perubahan struktur dan mempengaruhi sisi aktif sehingga surfaktan tersebut menjadi penghambat.

Surfaktan kationik pada pemakaian $0.05 \%$ relatif tidak berpengaruh terhada enzim lipase dari isolat AS, KB dan SP hal tersebut ditunjukkan dengan aktivitas relatifnya lebih besar dari $80.0 \%$, sedang pada konsentrasi $0.10 \%$ pemakain surfaktan kationik (cetyl trimethyl ammonium bromide) berpengaruh terhadap aktivitas enzim lipase yang berasal dari isolat AS-1, surfaktan cetyl dimetyl ammonium bromide berpengaruh terhadap aktivitas enzim lipase dari SP-2 dan SP-13 sedangkan cetyl piridium chloride berpengaruh terhadap aktivitas enzim lipase dar (Gambar 3b. dan Gambar 3c.), demikian juga surfaktan nonionik seperti Triton X-100 pada konsentrasi $1.0 \%$, menurunkan aktivitas relatif enzim lipase yang berasal dari AS-1 dan SP-13 (aktivitas relatifny: kurang dari AS-1 dan SP-13 (aktivitas relatifnya kurang dari 80.0\%).
AKTIVITAS RELATIF $\left(w_{0}\right)$

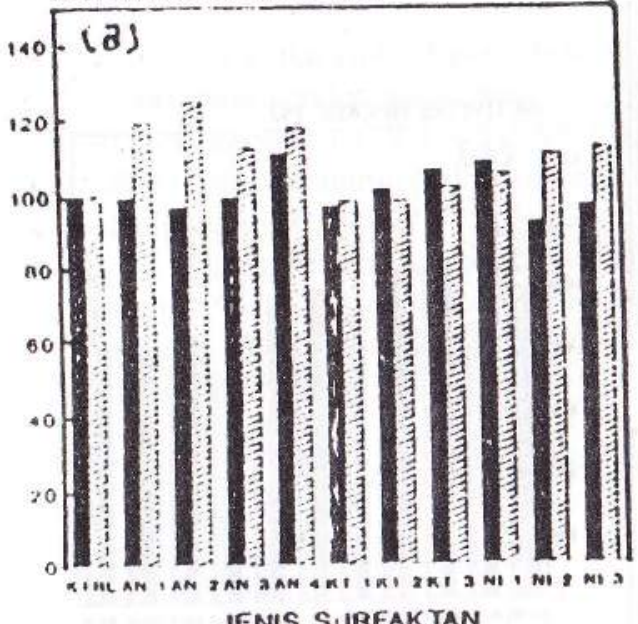

JENIS SURFAKTAN

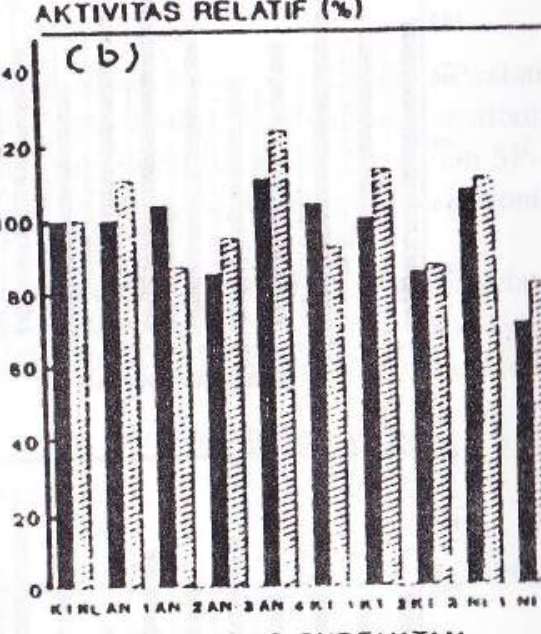

JENIS SURFAKTAN
Gambar 2. Pengaruh surfaktan terhadap aktivita. enzim lipase da $\mathrm{KB}-4$ (a) dan KB-8 (b)

Keterangan gambar lihat Gambar 1

Dari hasil penelitian dapat dinyatakan bahwa surfaktan anionik seperti ! lauroyl sarcosine, surfaktan kationik seperti cetyl pyridum chloride; cetyl din ethyl ammonium bromide dan nonionik yaitu Triton X-100 dan tergitol berpengar terhadap aktivitas relatif enzim lipase dari isolat SP-13 yaitu menurunkan aktivita Hasil tersebut berbeda dengan hasil penelitian yang dilakukan oleh Lin dkk (1990 yang melaporkan bahwa surfaktan nonionik seperti Triton X-100, Tween 80 d: Span 80 pada pemakaian $0.10 \%(\mathrm{~b} / \mathrm{v})$ berfungsi sebagai aktivator pada enzim yau dihasilkan oleh Neurospora sp. TT-241 

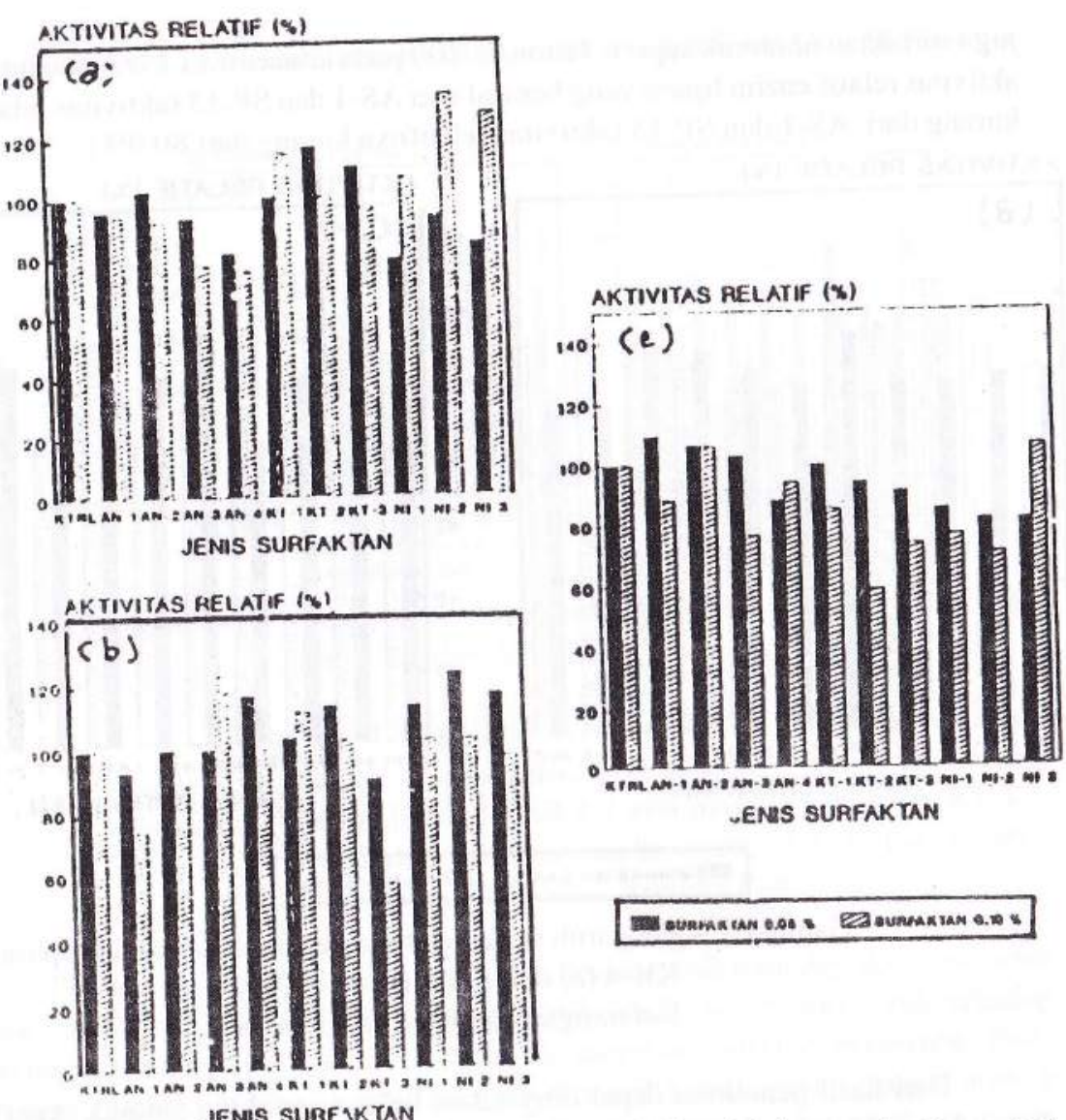

ENES SURFAKTAN

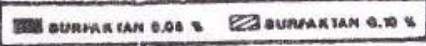

Pengaruh surfaktan terhadap aktivitas enzim lipase dari SP-1 (a), SP-2 (b) dan SP-13 (c)

Keterangan gambar lihat Gambar 1

Secara umum dapat dikatakan bahwa aktivitas enzim lipase alkali yang berasal dari bakteri ( Isolat AS ,KB dan SP) (pada kondisi yang mengandung surfaktan anionik, kationik $0,05 \%$ aktifitasnya relatif stabil (aktifitas relatif $<80$ $\%$ ),sedang surfaktan nonionik mempengarui aktifitas enzim lipase bakteri yang berasal dari isolat KB-8 dan SP-1 yaitu menurunkan aktivitasnya (aktivitas relatif $<80 \%$ ). Isolat yang menóproduksi enzim lipase alkali dan mempunyai aktivitas enzim relatif tinggi serta stabil pada kondisi yang mengandung surfaktan anionik ,kationik dan nonionik $0,05 \%$ dan $0,10 \%$ adalah isolat $\mathrm{KB}-4$, sedang isolat AS-1 hanya stabil pada kondisi yang mengadung surfaktan anionik ,kationik dan nonionik $0,05 \%$.Berdasar aktifitas relatifnya,enzim lipase alkali yang mempunyai aktivitas relatif tinggi (90-125)serta relatif stabil pada kondisi yang mengandung surfaktan anionik, kationik dan nonionik $0,05 \%$ dan $0,10 \%$ adalah enzim yang berasal dat isolat $\mathrm{KB}-4$.

\section{KESIMPULAN}

Aktivitas enzim lipase alkali yang berasal dari Isolat AS, KB dan SP ralat stabil pada kondisi yang mengandung surfaktan anionik, kationik dan nonioni $0,05 \%$, kecuali dari KB-8 dan SP-1. Enzim yang diproduksi dari KB-8 dan SPaktivitasnya menurun pada kondisi yang mengandung surfaktan anionik, kationi dan nonionik $0,05 \%$

Isolat yang memproduksi enzim lipase alkali dan mempunyai aktivitas relat tinggi $(90-125 \%)$ serta relatif stabil pada kondisi yang mengandung surfakta anionik, kationik dan nonionik $0,05 \%$ dan $0,10 \%$ adalah enzim yang berasal da isolat $\mathrm{KB}-4$

\section{DAFTAR PUSTAKA}

Brockerhoff, H., dan R.G. Jensen., 1974. Lipolytic Enzymes. Academic Press. Ne York.

Budiatman, S., D. Fardiaz., B. Nurtama., D. Robiatul., dan M. Gesang., 1993. L, poran Penelitian Proses Interesterifikasi Minyak Sawit dan Minyak In Sawit untuk Mendapatkan Produk-produk yang Bernilai Tinggi Taha, Penelusuran Teknik Proses. Proyek Penelitian dan Pengabdian pada Masyarakat. Pusat Antar Universitas Pangan dan Gizi, Institut Pertani: Bogor.

Crueger, W., dan A. Crueger., 1989. Biotechnology. A Textbook of Industrial M crobiology. Sinauer Associates, Inc. Sunderland, MA

Hammond, E.G., dan Glatz., 1988. Biotechnology Applied to Fats and Oils didala Food Biotechnology -2. Ed. R.D. King dan P.S.J. Cheetham. Elsevier Applied Science, New York.

Indarti, R., Rumiyati , V.S.P., dan Utami, T., 1998. Production of Alkaline Lipa from Kluyvera KB-4. Indonesion Food and Nutrition Progress. Vol. No. 1. Page $10-14$

Khor, H.T., N.H. Tan., dan C.L. Chua., 1986. Lipase Catalyzed Hydrolysis of I lp Oil. JAOCS., $63: 538$ - 540.

Kohno, M., W. Kugimiya., Y Hashimoto.,and Y. Morita., 1994. Purification, Characterization, and crystalization of Two Types of Lipase from Rhi pus niveus. Biosc. Biotech Biochem., 58 : 1007 - 1012. 
*) Aktivitas enzim lipase tanpa perlakuan dengan surfaktan

**) Hasil rata-rata 2 ulangan perlakuan dengan dua ulangan analisis

\begin{tabular}{|c|c|c|c|c|c|c|}
\hline \multirow{3}{*}{$\begin{array}{l}\text { JENIS } \\
\text { SURFAK } \\
\text { TANS }\end{array}$} & \multicolumn{6}{|c|}{ AKTIVTTAS RELATIF $(\%)$} \\
\hline & \multicolumn{2}{|c|}{ ISOLAT SP-1 } & \multicolumn{2}{|c|}{ ISOLAT SP-2 } & \multicolumn{2}{|c|}{ ISOLAT SP-13 } \\
\hline & $0.05 \%$ & $0.10 \%$ & $0.05 \%$ & $0.10 \%$ & $0.05 \%$ & $0.10 \%$ \\
\hline KONTROL* & 100 & 100 & 100 & 100 & 100 & 100 \\
\hline $\mathrm{AN}-1$ & 95.2381 & 93.75 & 93.3333 & 74.2857 & 109.0909 & 88.2353 \\
\hline AN-2 & 102.3809 & 91.6667 & 100 & 88.5714 & 106.0606 & 105.8823 \\
\hline AN-3 & 92.8571 & 77.0833 & 100 & 122.8571 & 103.0303 & 76.4706 \\
\hline $\mathrm{AN}-4$ & 80.9524 & 75 & 1166666 & 100 & 87.8788 & 94.1176 \\
\hline$K T-1$ & 100 & 114.5833 & 103.3333 & 111.4285 & 100 & 85.2941 \\
\hline $\mathrm{KT}-2$ & 116.6066 & 100 & 113.3333 & 102.8571 & 93.9354 & 58.8235 \\
\hline KT -3 & 109.5238 & 95.8333 & 90 & 57.1428 & 90.9091 & 73.5294 \\
\hline NI-I & 78.5714 & 106.25 & 113.3333 & 102.8571 & 84.8485 & 76.4706 \\
\hline NI-2 & 92.8571 & 133.3333 & 123.3333 & 102.8571 & 81.8182 & 70.5882 \\
\hline NI-3 & 83.3333 & 127.0833 & 116.6666 & 97.1428 & 81.8182 & 1058823 \\
\hline
\end{tabular}

*) Aktivitas enzim lipase tanpa perlakuan dengan surfaktan

**) Hasil rata-rata 2 ulangan perlakuan dengan dua ulangan analisis

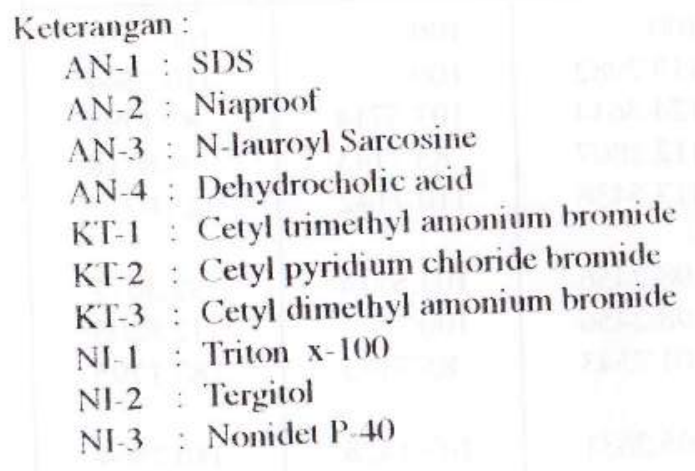


RALAT

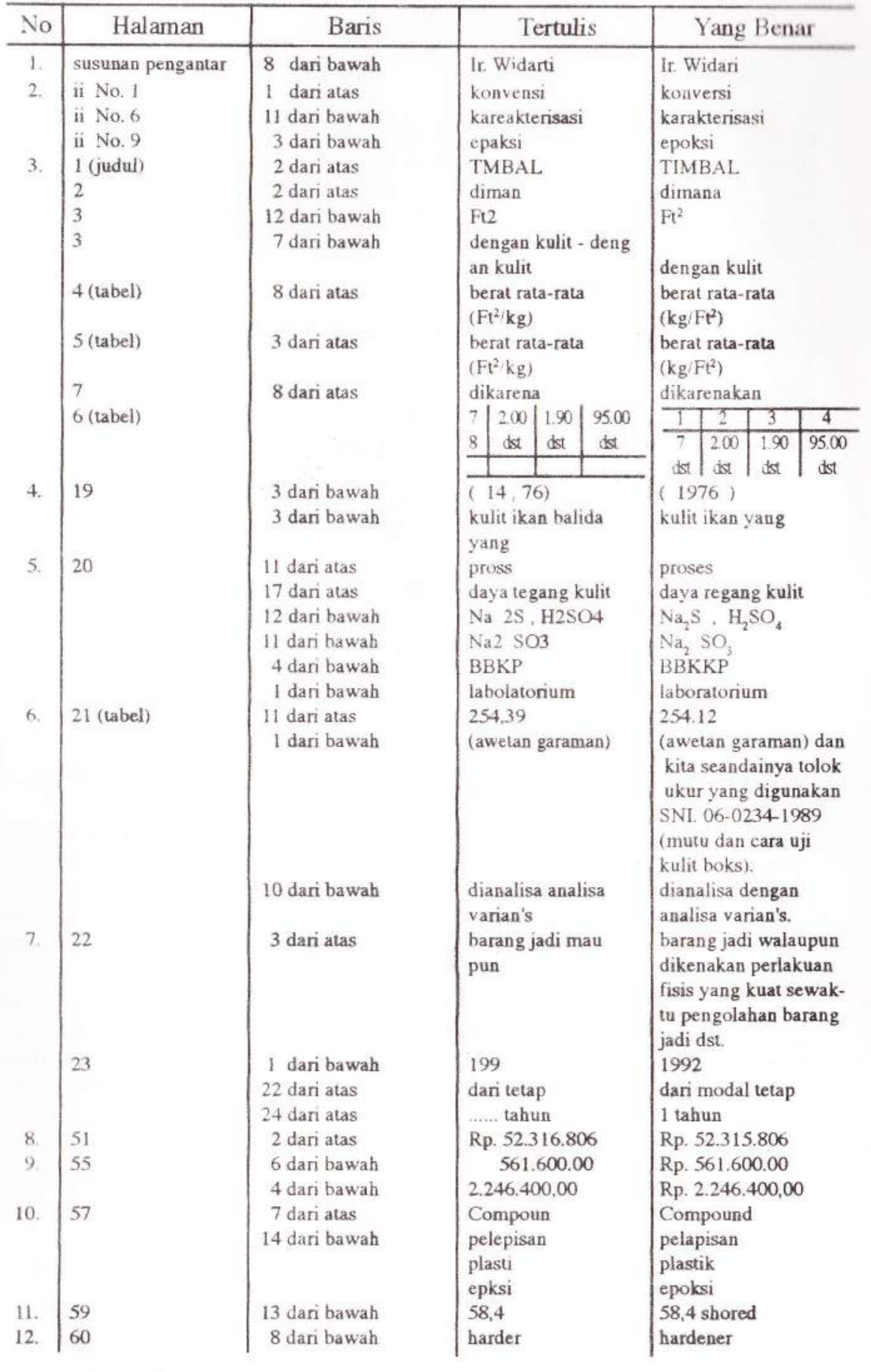

